\title{
Improving Self Independence and Adjustment-based Students' Language Competence through Self Access Center
}

\author{
Asep Samsudin*, Bachrudin Musthafa, Dadang Sunendar \\ IKIP Siliwangi, Universitas Pendidikan Indonesia, Indonesia
}

Received August 3, 2020; Revised October 14, 2020; Accepted November 1, 2020

\section{Cite This Paper in the following Citation Styles}

(a): [1] Asep Samsudin, Bachrudin Musthafa, Dadang Sunendar, "Improving Self Independence and Adjustment-based Students' Language Competence through Self Access Center, "Universal Journal of Educational Research, Vol. 8, No. 12, pp. 6473-6481, 2020. DOI: 10.13189/ujer.2020.081212.

(b): Asep Samsudin, Bachrudin Musthafa, Dadang Sunendar (2020). Improving Self Independence and Adjustment-based Students' Language Competence through Self Access Center. Universal Journal of Educational Research, 8(12), 6473-6481. DOI: 10.13189/ujer.2020.081212.

Copyright $\bigcirc 2020$ by authors, all rights reserved. Authors agree that this article remains permanently open access under the terms of the Creative Commons Attribution License 4.0 International License

\begin{abstract}
Self-Access Centre (SAC) originating from self-access language learning is expected to be an explorative learning that can make students content with learning language about new literacies and it is also easy for them to understand. In terms of independence concept, SAC is equipped by the facilities that support learning process consisting of applications and equipment. In related to the samples, the fourth-grade students are more interested to explore the learning process by using visual media and facilities that are packaged to attract their attention. The application of SAC facilities becomes a source of current information and an embodiment of technological integration with literacy that is easy for students to understand. The observation of such application is conducted every day in six months and the interview session is done in certain times when the students are free. This study uses qualitative methods aimed at knowing and understanding occurring phenomena, the learning process, or the views and input of the research subjects involved. The data collection is considered to be finished. On the research evidence evaluation stage, the NUD*IST software is implemented to search for emerging and developing themes and the evidences are collected based on these themes. Three categories, namely the construction of knowledge, language learning and the theories of listening and reading become more evident. In terms of knowledge construction, the sub-category of clarification, association and development is determined. The category of reading
\end{abstract}

contains process and product. Its sub-category is problem solving. The third category, the independent learning through SAC contains the sub-category of simplifying the learning style and independence. Based on the categories above, the theory of knowledge construction, learning \& problem solving, and learning through SAC is related to the students' experiences. The fourth category, integration of subjects, is intended to be an evidence containing reading skill. The fifth category, students' independence, is also influenced intentionally by the SAC program.

Keywords Self-independence, Self-adjustment, Language Competence, Self-accessed Center

\section{Introduction}

SAC originating from self-access language learning is expected to be an exploratory learning medium that can make students content in language learning about new literacies and it is easy for them to understand. SAC is a center for accessing various knowledge independently without teacher guidance [1]. In the concept of independence, SAC is equipped with facilities that support the learning process which consists of software and hardware. This has become a useful medium for school administrators and students themselves. The elementary 
school students at the age of class IV in Cimahi City, West Java Province, Indonesia, are more interested in visual media and facilities that are packaged to attract their attention, one of which is the application of SAC in school locations that are strategic and easily accessed by them as a source of current information and an embodiment of technological integration with literacy that is very easy to understand. In related to language, there are four language competences; listening, speaking, reading and writing.

According to [2], listening activity is a process of listening carefully to verbal symbols with full attention, understanding, appreciation, and interpretation, to obtain information, capture content, and understand the meaning conveyed by speakers through speech. It is a process that includes listening to language sounds, identifying, interpreting, evaluating, and reacting to the meanings contained therein. Listening involves sight, appreciation, memory, understanding, and the situation that accompanies the sound of the listening language. So, it can be concluded that listening is a process that includes listening to the symbols of spoken language by using ears, attentive, understanding, appreciation and interpretation to obtain information, capture content or messages and understand the meaning of communication delivered nonverbally.

In relation to speaking, some linguists have defined the notion of speaking. Speaking is essentially a process of communication, because there is a message in it from one source to another [3]. From the understanding that has been mentioned, it can be concluded that speaking is a process to express and convey thoughts, ideas, or contents to others by using language that can be understood by others.

The next skill is reading. To read as reading is a process that involves sensory activity and thinking to enter information from written sources and translate it into the mind. Dalman states that reading is a cognitive process that seeks to find various information contained in readings [4]. The statement shows that reading involves the process of translating symbols in reading to get information. Farida mentions that reading is essentially a complex thing that involves many things, not just reciting writing, but also involves visual, thinking, psycholinguistic, and metacognitive activities [5].

Klein, et all. in Farida argues that the definition of reading includes (1) reading is a process, (2) reading is strategic, and (3) reading is interactive [5]. Reading is a process of forming the meaning of information from the text using the knowledge possessed by the reader. Reading as a strategy means that the reader uses various strategies to construct meaning when reading. Reading is interactive means there is involvement between the reader and the text that is read according to context.
The last one is writing. Writing is a person's ability to express ideas, thoughts, knowledge, knowledge and life experiences in written language that is clear, coherent, expressive, readable and can be understood by others [6]. Writing is a whole series of activities someone expresses ideas and convey them through written language to the reader to be understood [7]. Based on some of the opinions above it can be concluded that writing is a person's ability to express ideas, thoughts, knowledge and life experiences through clear written language so that the reader understands what the writer meant.

In the meantime, self-independence is the ability to take and account for the actions taken and to establish supportive relationships with others [8]. Independence as the ability to make decisions and make himself a source of emotional strength so that he does not depend on others [9]. Some experts claim that to achieve independence means freeing yourself from the bonds of parents in order to develop their identity [10].

Conceptually, independence refers to the capacity of individuals to treat themselves. The independence generally refers to individuals' capacity to behave on their own [8]. Based on the concept of independence, Steinberg explains that a child who has achieved independence is able to run or carry out his own life activities regardless of the influence of other people's control, especially parents [8]. For example, when a child wants to urinate, he goes straight to the toilet, does not whine to ask for help to open his pants or ask to find a place to urinate.

In related to learning processes, that educational activities which create learners' independence as much as possible will also help them to be more competent persons [11]. Based on this statement, it can be said that learning activities like in Self Access Center (SAC), which in this research is used for language learning, can also improve learners' language competences, namely speaking, listening, reading and writing.

On one hand, adjustment refers to the extent to which an individual's personality functions efficiently in society [12]. It is a human effort to achieve harmony in oneself and the environment [13]. Adjustment is a process to find a meeting point between one's own condition and environmental demands [14]. The adjustment made by individuals can be understood as an outcome (achievement) and or as a process [15].

In related to learning processes, creating a good learning environment just like SAC which in this research is used for language learning, then, children's self-adjustment will also improve and so will their language competences, namely speaking, listening, reading, and writing [16]. 


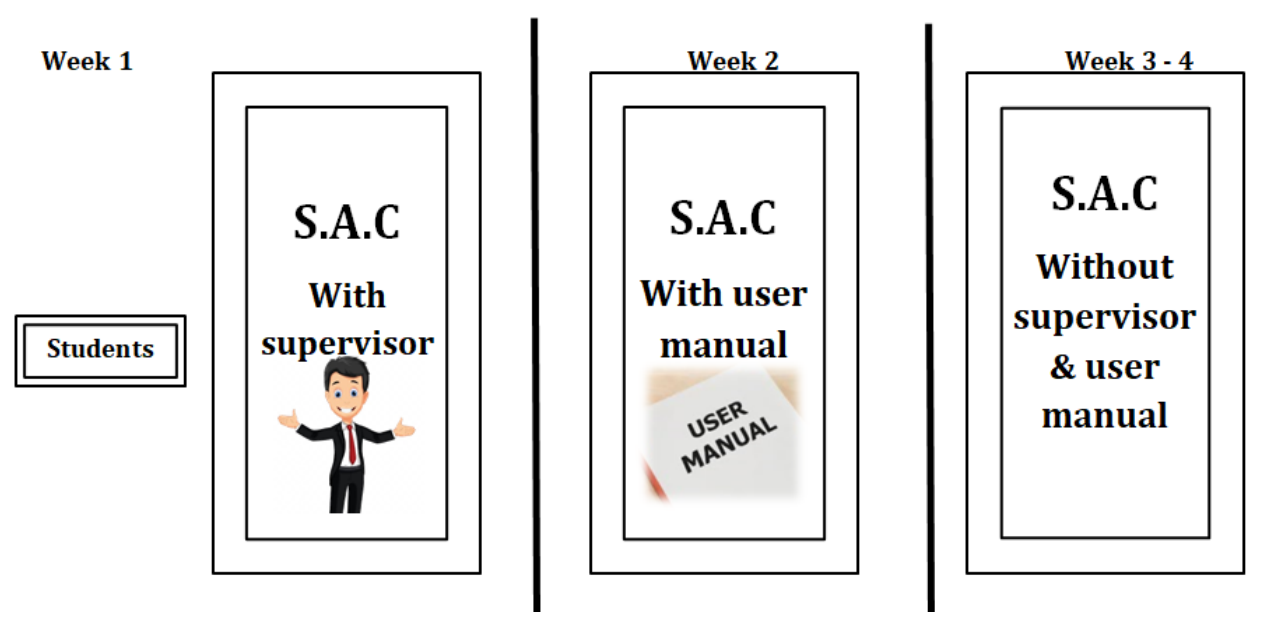

Figure 1 The Setting of SAC

\section{Improving Students' Self-independence and Adjustment}

The process of improving students' self-independence and adjustment is explained by the picture above.

\section{Explanation:}

In Week 1, the students are given the opportunity to see the situation in S.A.C environment directly and visually without making them feel embarrassed and afraid. They are also assisted by the researcher and supervisor who give them guidance on how to access teaching materials in SAC facilities.

In Week 2, the students enter SAC Class without the supervisor. They are only given the user manual. This manual contains the instruction on how to operate S.A.C facilities.

In Week 3-4, the students are given the freedom to enter the S.A.C Class designed without the supervisor and user manual. Equipment design at S.A.C enables them to enter S.A.C to carry out learning independently according to what they need.

\section{Research Question}

Based on the Introduction above, so, the question of this research is as follows: How can the students develop their language skills through the development of Self Access Centre (SAC) learning environment?

\section{Methodology}

This study uses qualitative methods aimed at knowing and understanding occurring phenomena, the learning process, or the views and input of the research subjects involved [17]. Forms of exploration and phenomena in the SAC learning environment in children in developing language competence are the focus of research, specifically the use of Self Access Centers (SAC) based on independence and adaptation of elementary school students.
Data was collected through interviews that were supported by observations and research documents. The findings of this study are compiled in a descriptive qualitative analysis. The population of this study is two classes of grade IV students of Elementary School Kartika XIX-4 in Cimahi City, West Java Province, Indonesia. By using purposive sampling, the sample is one class of grade IV. This sample supports the information to be analyzed. (Patton, 1990). The criteria for selecting these samples are based on the purpose of the study and the theoretical basis that is consistent with the study. This study uses qualitative methods aimed at knowing and understanding occurring phenomena, the learning process, or the views and input of the research subjects involved.

In this study, evidences are obtained during observations and interviews through the use of instruments developed from the pre-research stage and literature review. These observations were carried out every day for six months by recording students' SAC activities through video and taking pictures, along with interviews conducted to each student participant for two times. Satisfaction of information gathering is considered complete, when information sources have fulfilled what is desired, the categories as new information no longer exist and evidence will be predicted [18]. After gathering the information above, the evidence is managed and compiled into a qualitative evidence evaluation software program called NUD * IST.

In the evaluation stage of research evidence, NUD * IST software is used to look for emerging themes and gather evidence based on those themes. Three categories, namely knowledge construction, language learning and theories of language competency development, become apparent. Within the knowledge construction category, clarification, association and knowledge development subcategories are established. The language competency category includes processes and products. The language competency category contains the problem- solving subcategory. The third category, independent learning and self-adjustment through self-access center (SAC), includes subcategories facilitating learning styles by adjusting to and 
independence of children.

\section{Result and Discussion}

In this study, the researchers produced findings, namely the development of language competence, the development of independence and the form of exploration adaptation for fourth grade students of SD Kartika XIX-4 as seen from the achievements and long observations through the establishment of SAC learning environments that focus on listening ability, ability speaking, reading skills, and writing skills. This study uses unbalanced rating scales, namely Poor, Fair, Good, and Very Good [19]. By using Nud*ist Software which is exported to Excell, the researcher compiled a series of findings based on the data of students' independence and adjustment, SAC learning environment, and the students' language competence arranged as follows:

Table 1. Data of Findings Series

\begin{tabular}{|c|c|c|c|c|c|}
\hline \multirow{2}{*}{ ASSESSMENT } & \multirow{2}{*}{ INDICATORS } & \multicolumn{4}{|c|}{ PERCENTAGE } \\
\hline & & POOR & FAIR & GOOD & VERY GOOD \\
\hline \multirow{5}{*}{$\begin{array}{l}\text { Students' Self } \\
\text { Independence }\end{array}$} & Confidence & 0 & 24 & 36 & 40 \\
\hline & Evaluation & 0 & 16 & 24 & 60 \\
\hline & Motivation & 4 & 20 & 32 & 48 \\
\hline & Problem Solving & 0 & 28 & 24 & 48 \\
\hline & Responsibility & 4 & 20 & 28 & 52 \\
\hline \multicolumn{2}{|r|}{ Means } & 1,60 & 21,60 & 28,80 & 49,60 \\
\hline \multirow{3}{*}{$\begin{array}{l}\text { Students' Self } \\
\text { Adjustment }\end{array}$} & Social Competence & 4 & 20 & 32 & 48 \\
\hline & Feed Back & 0 & 16 & 24 & 60 \\
\hline & Needs & 0 & 12 & 36 & 52 \\
\hline \multicolumn{2}{|r|}{ Means } & 1,33 & 16,00 & 30,67 & 53,33 \\
\hline \multirow{7}{*}{$\begin{array}{c}\text { SAC } \\
\text { Environment }\end{array}$} & Adaptive & 0 & 32 & 40 & 28 \\
\hline & Effective & 0 & 28 & 16 & 56 \\
\hline & Explore & 0 & 24 & 44 & 32 \\
\hline & Interactive & 0 & 32 & 28 & 40 \\
\hline & Learning Opportunity & 0 & 16 & 24 & 60 \\
\hline & Product and facility & 0 & 20 & 44 & 36 \\
\hline & Sources & 4 & 8 & 44 & 44 \\
\hline \multicolumn{2}{|r|}{ Means } & $\mathbf{0 , 5 7}$ & 22,86 & 34,29 & 42,29 \\
\hline \multirow{4}{*}{ WRITING } & Economic & 0 & 12 & 24 & 64 \\
\hline & Clear & 0 & 20 & 36 & 44 \\
\hline & Cohesion & 0 & 32 & 48 & 20 \\
\hline & Language use can be accepted & 0 & 16 & 20 & 64 \\
\hline \multicolumn{2}{|r|}{ Means } & $\mathbf{0 , 0 0}$ & $\mathbf{2 0 , 0 0}$ & 32,00 & 48,00 \\
\hline \multirow{3}{*}{ READING } & Decoding & 0 & 24 & 32 & 44 \\
\hline & Meaning & 0 & 24 & 52 & 24 \\
\hline & Record & 0 & 44 & 28 & 28 \\
\hline \multicolumn{2}{|r|}{ Means } & $\mathbf{0 , 0 0}$ & 30,67 & 37,33 & 32,00 \\
\hline \multirow{3}{*}{ SPEAKING } & Information & 0 & 36 & 24 & 40 \\
\hline & Participate & 0 & 16 & 20 & 64 \\
\hline & Speaking & 0 & 32 & 48 & 20 \\
\hline \multicolumn{2}{|r|}{ Means } & $\mathbf{0 , 0 0}$ & 28,00 & 30,67 & 41,33 \\
\hline \multirow{5}{*}{ LISTENING } & Recite & 0 & 20 & 56 & 24 \\
\hline & Record & 0 & 20 & 48 & 32 \\
\hline & Reduce & 0 & 20 & 12 & 68 \\
\hline & Reflect & 0 & 16 & 36 & 44 \\
\hline & Review & 0 & 28 & 24 & 48 \\
\hline \multicolumn{2}{|r|}{ Means } & 0,00 & 20,80 & 35,20 & 43,20 \\
\hline
\end{tabular}


Based on the table above, there exist students' independence and adjustment in improving language skills in the formation of the SAC learning environment, all observations in this study resulted in:

\section{Students' Independence}

In the independence of children in SAC has resulted in the impact of the existence of the SAC learning environment seen from the following aspects, namely:

a. Confidence, in this aspect, as many as $40 \%$ students have confidence in doing their assignments very well.

b. Evaluation, this aspect is the same as the aspect of responsibility which shows that $60 \%$ of students have done a very good evaluation of learning.

c. Motivation, this aspect provides the highest value, which is as many as $48 \%$ students have excellent learning motivation. So that the existence of this SAC has a very big impact on the motivation of students to want to learn.

d. Problem Solving, in this aspect, the assessment of problem-solving shows as many as $48 \%$ students have excellent criteria. This shows that through SAC the students are able to solve problems very well. e. Responsibility, in this aspect, as many as $52 \%$ of students already have excellent criteria in responsibility for the tasks and learning outcomes at SAC.

\section{Students' Adjustment}

a. Social Competence, this aspect gives $48 \%$ of the assessment and show that students can adjust very well in learning various social skills such as the ability to establish relationships with friends, so they feel happy to be in the SAC learning environment.

b. Feed Back, this aspect has a very high assessment as many as $60 \%$ students are trying to create situations and conditions that match between students with the SAC environment so as to get excellent feedback for students.

c. Needs, in this aspect showed 52\% students felt they had fulfilled the need to strike a balance between abilities and expectations within themselves very well.

The data of students' independence and adjustment above can be explained by the graphic below:

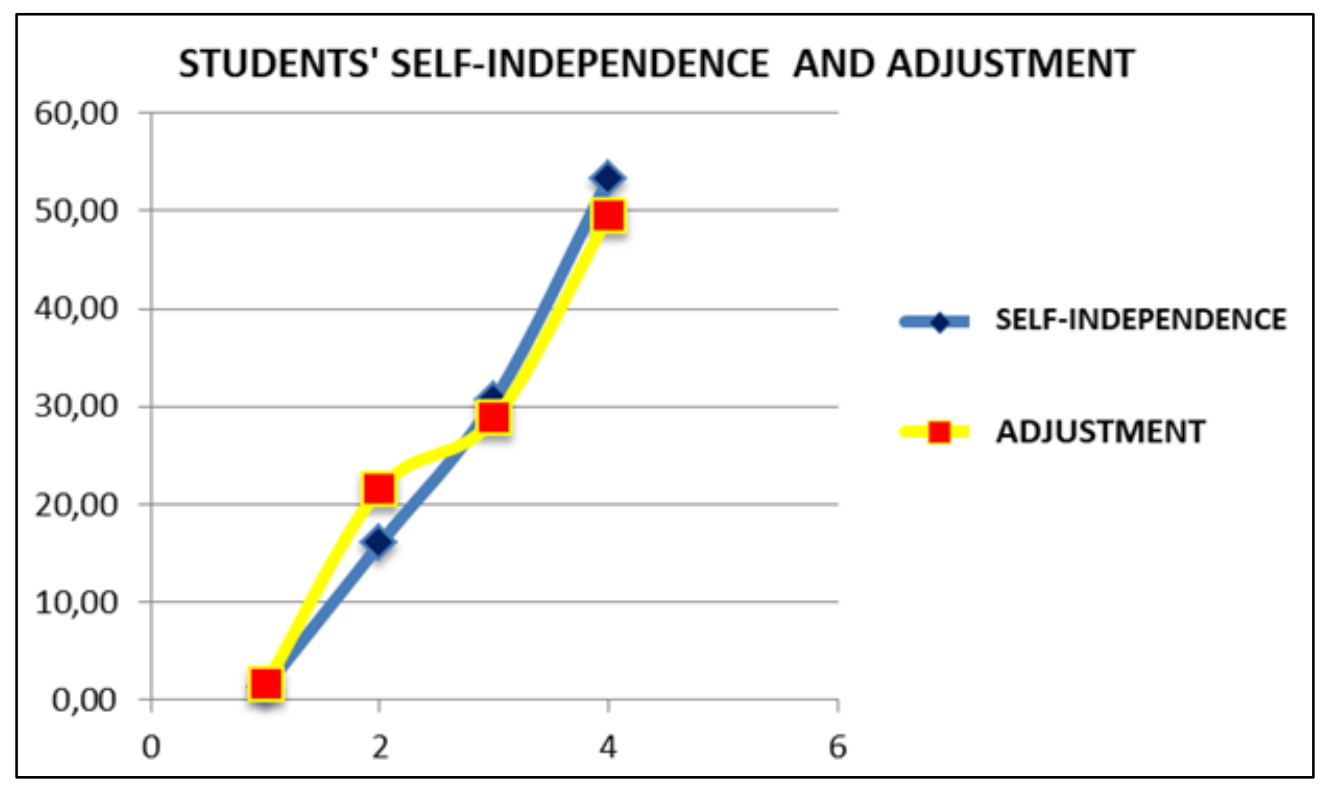

Figure 2 The data of students' independence and adjustment 


\section{SAC Learning Environment}

The SAC learning environment which must have 7 aspects has helped by $25 \%$ towards the development of elementary school students' language competency in SD Kartika XIX-4 Cimahi City. This is based on long observations and observations from various aspects, namely:

a. Adaptive, this aspect provides a Good response, with $40 \%$ positive responses from students and teachers stating that SAC has made students more involved in their learning process and able to adapt well through different ways of learning.

b. Effective, this aspect provides Very Good criteria, with a total response of $56 \%$ from students and teachers. This shows that SAC is effective for students in learning language skills in the SAC learning environment.

c. Explore, this aspect gave a Good response given by $44 \%$ of students and teachers. This illustrates that SAC has provided students to be able to explore new learning experiences in the SAC learning environment very well. d. Interactive, this aspect has given a high rating as of $40 \%$ of students and teachers giving Very Good responses, stating that SAC provides a unique learning experience where each student is able to interact with the environment to make decisions about the learning they want very well.

e. Learning Opportunity, in this aspect, $60 \%$ of students and teachers responded that SAC had Very Good criteria which said that SAC had created a learning environment that could improve children's language skills.

f. Product and Facility, this aspect gets a Good criteria with the acquisition of an equal percentage of $44 \%$. This illustrates that SAC has provided direct experience to students independently using source books, audio, video, computers and programs found in the SAC learning environment.

g. Sources, this aspect shows that SAC has a balance between Good and Very Good Criteria as many as $44 \%$. This illustrates that SAC has used good materials and resources in the SAC learning environment.

The data of SAC Existence above can be explained by the graphic below:

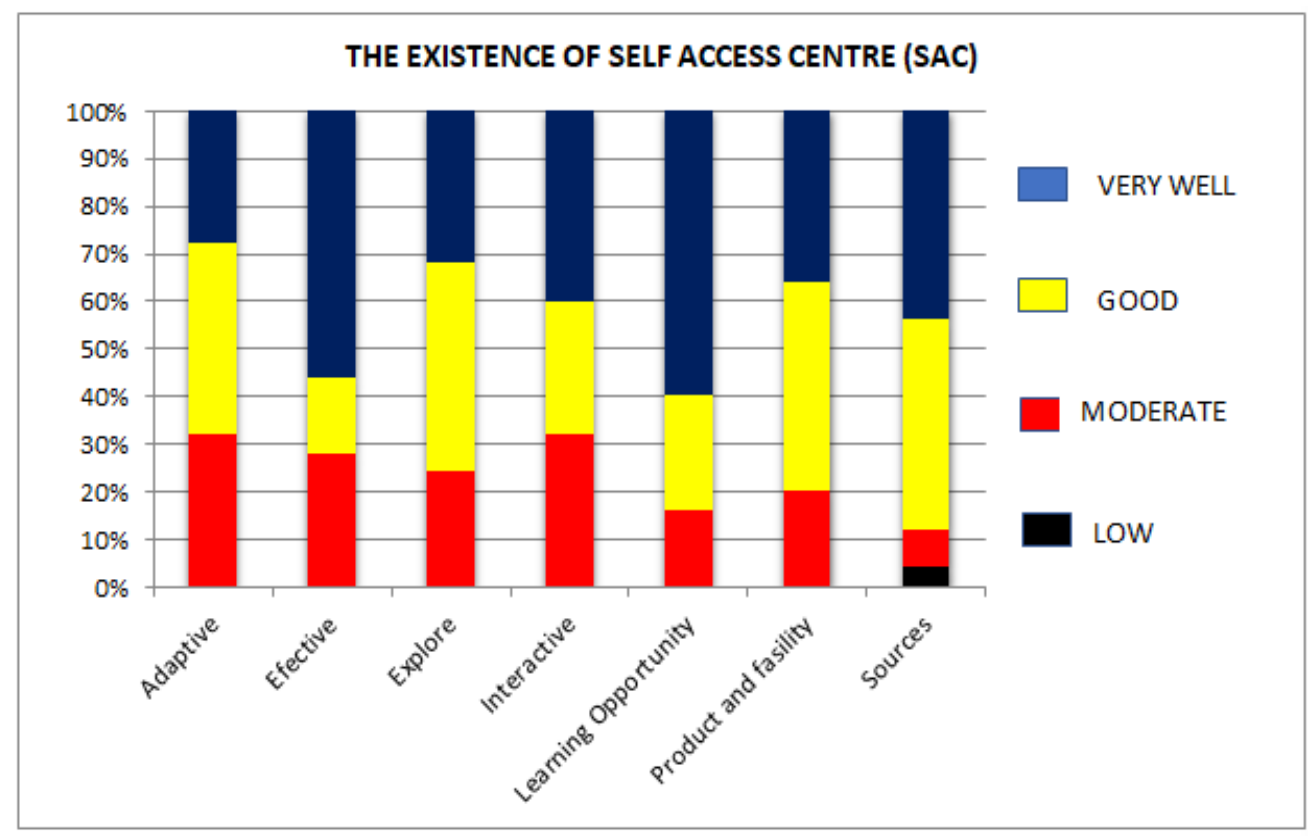

Figure 3 The Existence of SAC 


\section{Students' Language Competences}

In the process of writing, students demonstrate abilities from various aspects, including:

a. Economically, this stage shows that $64 \%$ of students still use excessive words or language, so the criteria for this assessment are Very Good.

b. Clearly, at this stage students as many as $44 \%$ enter the criteria Very Good. This illustrates that they are already able to write texts very well, so that readers can read texts in a fixed way and the reader is not confused and is able to grasp meaning without having to reread from the beginning.

c. Cohesion, in this stage, the students are already able to make the reader follow the writing very easily. The percentage of students who have been able to carry out reaches $48 \%$ with Good criteria.

d. The use of language is acceptable, at this stage, the students as many as $64 \%$ are already able to use good and correct language very well.

In the reading process, students demonstrate abilities from various aspects, including:

a. Decoding, this stage is carried out by $44 \%$ students with very good criteria. This shows that students are able to carry out the process of translating a series of graphics into words well.

b. Meaning, at this stage the students only enter the criteria of Good with the number of students as many as $52 \%$. This is because in understanding the meaning of a reading requires a long adaptation process and is influenced by his friends who are not interested in entering the SAC learning environment.

c. Record, at this stage, students as many as $44 \%$ are already able to associate words and sentences with their sounds in accordance with the writing system used at SAC. This shows that students fit into the criteria Moderate.

In the process of speaking, students demonstrate abilities from various aspects, including:

a. Information, in this stage, as many as $40 \%$ students are already able to carry out four aspects of information, namely conveying information to friends in a higher class, confident in speaking, able to arrange and present a conversation and able to learn the best way to speak in front of a number of listeners.
Therefore, from these observations and assessments, students enter the criteria very well.

b. Participate, five aspects contained in this stage have been implemented by students, namely participation in discussions, interacting with other students and teachers, expressing in full, presenting opinions and considering changing opinions themselves. All aspects were carried out by as many as $64 \%$ of students with very good criteria.

c. Speaking, this stage was the highest stage in speaking, so that as many as $48 \%$ of students were only able to carry out five of the six aspects, namely presenting performances, presenting performances to friends, being able to tell stories, being able to read poetry and students being able to participate in drama performances. One aspect that has yet to be implemented is speaking comforting and being able to talk with parents and the community. Therefore, at this stage students get Good criteria.

In the listening process, students demonstrate abilities from various aspects, including:

a. Recite, this aspect shows that students are able to have $56 \%$ with Good criteria. This illustrates that students are able to use sentences in sequence based on their own interpretation very well.

b. Record, students in this stage have $48 \%$ with Good criteria. This illustrates that students have been able to get ideas out of what is being watched through the media in the SAC learning environment.

c. Reduce, at this stage the students have reached $68 \%$ with Very Good criteria. This stage illustrates the students have been able to make a selection of keywords / key phrases to understand the explanation of a medium in SAC.

d. Reflect, in this stage, $44 \%$ of students have been able to get the criteria very well. This illustrates that students are able to explain logically and are able to issue students' opinions very well based on the media contained in the SAC.

e. Review, the stage the students are already able to absorb, memorize difficult words and be able to explain very well all the words obtained from the SAC media. The criteria at this stage are Very Good as many as $48 \%$. 


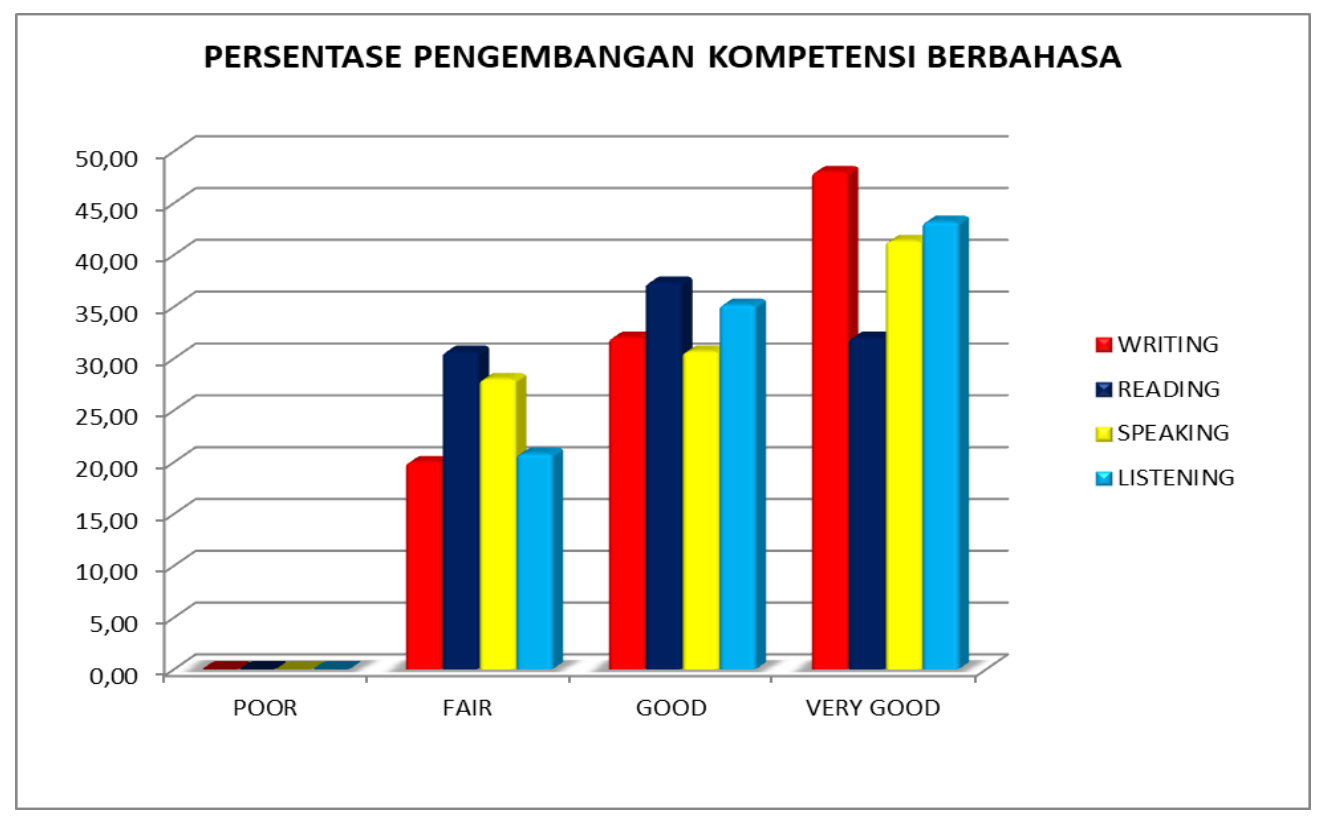

Figure 4 Percentage of Language Competence Development

\section{Conclusions}

Through this study, all data produced shows that the results of the students' independence and adjustment through SAC learning have helped the development of their language competences. This is supported by the establishment of SAC learning environment that can make students happy to be in SAC with a new atmosphere and a lot of attraction for students in language learning. Aside from language skills, they also demonstrate independence and adaptation which gives them the freedom to explore all language skills in SAC. Therefore, this study can provide a real picture and contribution to learning outside the classroom with a learning environment setting that can make students happy to be in SAC.

\section{REFERENCES}

[1] L. Yahya, "Pemanfaatan Self-Access Centre (Sac) Untuk Meningkatkan Keterampilan Membaca Bahasa Arab Dengan Metode Tutor Sebaya," in Prosiding : Konferensi Nasional Bahasa Arab 111, 2017, no. 5, pp. 65-71.

[2] H. G. Tarigan, Menyimak sebagai suatu keterampilan berbahasa, Revisi 200. Bandung: Angkasa - Bandung, 1986.

[3] Haryadi \& Zamzami, "Peningkatan Keterampilan Berbahasa Indonesia," Yogyakarta, Depdikbud, vol., no., p., 1996.

[4] Dalman, Keterampilan Membaca, 1st ed. Jakarta: Rajawali Pers, 2013.

[5] R. Farida, Pengajaran membaca di sekolah dasar, 1st ed. Jakarta: Bumi Aksara, 2005.
[6] Marwoto, Dasar - Dasar Keterampilan Menulis. Jakarta: Depdikbud, 1985.

[7] T. L. Gie, Administrasi Perkantoran Modern, 4th ed. Yogyakarta: Liberti, 1992.

[8] L. Steinberg and A. Morris, "Adolescent development," $J$. Cogn. Educ. Psychol., vol. 52, no. 18, pp. 83-110, 2001, doi: 10.1891/194589501787383444.

[9] D. R. Shaffer and K. Katherine, DevelopmentalPsychology; Childhood and Adolescence, 8th ed., vol. Eight Edit, no. 8. Canada: Wadsworth, Cengage LEarning.

[10] I. S. Wardani and A. Samsudin, "Kemandirian Anak Melalui Self Access Centre Dalam Mengembangkan Top 10 Skill,", Didakt. TAUHIDI J. Pendidik. Guru Sekol. Dasar, vol. 6, no. 1, p. 15, 2019, doi: 10.30997/dt.v6i1.1632.

[11] A. L. Wenden, "Learner training in foreign/second language learning: A curricular perspective for the 21 st century," $p$. 85, 1998.

[12] E. B. Hurlock, Perkembangan anak, 6th ed. Jakarta: Erlangga, 2007.

[13] Hartono \& Sunarto, Perkembangan Peserta Didik. Jakarta: Rineka Cipta, 2008.

[14] Z. Mu'tadin, “Kemandirian Sebagai Kebutuhan Psikologis Pada Remaja," E. Psikol., vol. 6, no. 2, pp. 51-62, 2002.

[15] S. Vembriarto, Sosiologi Pendidikan. Jakarta: Grasindo, 1993.

[16] S. Chung, Q. Zhou, C. Anicama, C. Rivera, and Y. Uchikoshi, "Language Proficiency, Parenting Styles, and Socioemotional Adjustment of Young Dual Language Learners," J. Cross. Cult. Psychol., vol. 50, no. 7, pp. 896914, 2019, doi: 10.1177/0022022119867394.

[17] S. B. Merriam, Qualitative Research and Case Study Applications in Education. Revised and Expanded from "Case Study Research in Education. San Fransisco, 1998. 
[18] Yvonna S Lincoln; Egon G Guba, Naturalistic inquiry. [19] Hershey H. Friedman, "Rating the Rating Scales," J. Mark. Beverly Hills, Calif: Sage Publications, 1985. Manag., vol. 9, no. 3, pp. 114-123, 1999. 